\title{
Perceived Stigmatization and Emotional Quotient of the Homeless Adolescents
}

\author{
Ulanday, Ma. Leah Pacleb, Abando, Marie Christine A., Belardo, Einon Dane Kryzl O., Loreto, \\ Efephany Joy N.
}

\begin{abstract}
Homeless adolescents nowadays learn how to survive alone, since no adult takes responsibility of them. They live or rather struggle to survive usually in the places near shopping malls, stations and offices, and other places which are lit up at night or in markets, in railway stations and even under bridges. With this fact, the amount of stigmatization they receive from the people who manage to insult while seeing them could be high and in that situation can be resulted to a higher stress and unfortunately could affect their emotions. This study is intended to determine the relationship between stigmatization and emotional quotient of homeless young adolescents with the aim of creating an intervention program within the results. This study used purposive sampling techniques in selecting the respondents wherein only those people without a home, and therefore typically living on the streets and belongs to age of 13-19 years old were included as respondents for a total of 70 . The method used descriptive- correlational design. The results on the relationship between variables perceived stigmatization and emotional quotient of the homeless adolescent shows that there is no significant relationship. It can be inferred that the level of perceived stigmatization of the participants has no impacts to the emotional quotient of the homeless adolescents. Moreover, homeless adolescent tend to look at the brighter side and became more positive in life to accept their situations.
\end{abstract}

Keywords: Emotional quotient, Homeless adolescents Stigmatization

\section{INTRODUCTION}

Homeless individuals constantly fight an uphill battle aligned with a stigma that creates in them a lost sense of self, that keeps them in their place and incapable to move forward and that stigma is for the most part universal but one that keeps them stagnant and unable to advance [1]. One of the causes for being homeless is poverty. Many of the researchers studied about the homeless and their perceived stigmatization but there are few who studied the homeless adolescents. And however, as cited by Global Homelessness Statistics, there are around 4.5 million homeless Filipinos with 3 million in Manila, which could possibly the most in any city in the world.

Revised Manuscript Received on March 13, 2020.

* Correspondence Author

Ma. Leah Pacleb Ulanday*, Cavite State University- Silang Campus Email: lpulanday@cvsu.edu.ph/airamleeyah@gmail.com

Abando, Marie Christine A., Cavite State University- Silang Campus. Email: marieabando@yahoo.com

Belardo, Einon Dane Kryzl O. Cavite State University- Silang Campus. Email: einondanekryzlbelardo@yahoo.com

Loreto, Efephany Joy N., Cavite State University- Silang Campus. Email: efephanyjoyloreto@gmail.com

(C) The Authors. Published by Blue Eyes Intelligence Engineering and Sciences Publication (BEIESP). This is an open access article under the CC BY-NC-ND license (http://creativecommons.org/licenses/by-nc-nd/4.0/)
There are reasons to believe that, given the highly stigmatized nature of homelessness, individuals who are homeless may have inadequate opportunities to join groups that may defend their well-being when facing discrimination [2]. And for those homeless, most of them are bear in a high level of stress from their lack of control over their situation and as a result, those homeless are not only suffer personal and economic hardship but also frequently face discrimination and exclusion because of their house status [3]. Also it was stated on the study of [4] that the effects of homelessness also lead to many emotional issues like the loss of self-esteem, loss of the ability to care for one's self, many homeless become depressed and have many behavior problems and can somehow affects their mental health.

Emotional Quotient is referred to as the capability to distinguish, evaluate and regulate the own emotions, emotions of those around you and emotions in groups of people [5]. Many studies were coping up on the stigmatization of the homeless but few were studied about the emotional intelligence of them. Since [6] stated that there are studies that provide valuable insights into how emotional intelligence can be a valuable tool in dealing with intergroup relations and shines light on the idea that prejudice towards an out-group could be fueled by an inability to recognize emotions that can relate through homeless people.

Furthermore, the aim of the study is for the researchers to prove that stigmatization they perceived is one of the major concerns of the homeless adolescents. And through this study, the researchers also want to recognize if there is a relationship between the perceived stigmatization and emotional quotient of the homeless adolescents.

\section{METHODOLOGY}

Descriptive and correlational design was used in this study. Descriptive design was employed to describe the variables of the each group in the study. Correlation design was utilized to measure and determined the relationship between the perceived stigmatization and emotional quotient of homeless young adolescence.

\section{Respondents}

Through purposive sampling techniques in selecting its respondents wherein only those people without a home, and therefore typically living on the streets and belongs to age of 13-19 years old were included as respondents for a total of 70

\section{Sources of data}

The primary source of data came from the adopted and modified survey questionnaires, Stigma Scale and Emotional Intelligence Questionnaire, which is given to the homeless adolescents in Dasmarinas City, Cavite.

Published By:

Blue Eyes Intelligence Engineering \& Sciences Publication

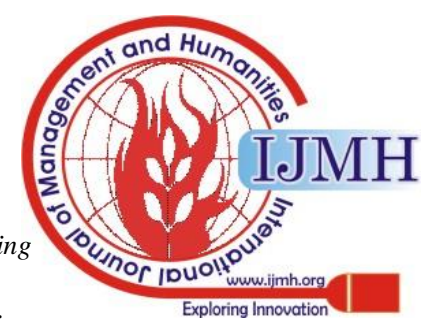




\section{Perceived Stigmatization and Emotional Quotient of the Homeless Adolescents}

The researchers also collected related literatures from primary and secondary sources such as online journals, online articles, websites, thesis and previous research.

\section{Data Gathering Procedure}

The conceptualization of the study was influenced by the other research studies about homeless. Since, the researchers scrutinize that the people were lack of attention about the welfare of a homeless and that was the reason why they came up with this kind of study.

In this study, the researcher acquired the permission to the Municipality's of Social Welfare Development to give the possible list of homeless individual who are living in their community. Also asked an informed consent and explained to the respondent about the instrument will administer by the researchers. Together with the permission is to accompany the researchers to manage their instruments and also to guarantee their safety. On the other hand, the researchers enlightened first the flow of the survey questionnaire for their better understanding about how and what they do on survey questionnaire. Moreover, the researchers assured the confidentiality about the answers of the respondents of this study. Then after conducted the survey the researchers are able to analyze the collected data and consulted to the statistician for the interpretation of the whole study

\section{Statistical Analysis}

The following statistical techniques in analyzing the data gathered were used:

The Mean and Standard Deviation was used to determine the perceived stigmatization and emotional quotient of homeless young adolescence. Mean was used to get the average scores of data by its population. And standard deviation was used to also determine how to disperse the data collected.

The Spearman's rho was used to measure and determine the relationship between perceive stigmatization and level of emotional quotient of homeless young adolescence.

\section{RESULTS AND DISCUSSION}

Data analysis was done using the descriptive statistics, specifically the computation of the weighted mean percentage and Spearman's rho was used to measure and determine the relationship between perceive stigmatization and level of emotional quotient of homeless young adolescence.

Table 1 shows the age of the participants. The results showed that the homeless adolescents whose age of 16 has the highest frequency of 14 , followed by the 13 years old with a frequency of 12 , then 18 years old with the frequency of 11 , 15 years old with a frequency of 10 , then 17 years old with a frequency of 9 , and the 14 and 19 years old got a frequency of 7 and it is the lowest frequency.

Table I. Frequency and percentage of the age of respondents

\begin{tabular}{|c|c|c|}
\hline AGE & FREQUENCY & PERCENTAGE \\
\hline 13 & 12 & 17.14 \\
14 & 7 & 10 \\
15 & 10 & 14.29 \\
16 & 14 & 20 \\
17 & 9 & 12.86 \\
18 & 11 & 15.71 \\
19 & 7 & 10 \\
\hline TOTAL & $\mathbf{7 0}$ & $\mathbf{1 0 0} \%$ \\
\hline
\end{tabular}

Homeless adolescents comprise about $1-3 \%$ of the children's population of major cities in the Philippines. Studies show that most are boys with ages of 7-16 years and living or working on the streets is viewed as a violation of the rights of children.

\section{Perceived Stigmatization of Homeless Adolescents}

Table 2 shows the level of perceived stigmatization of the respondents. Overall, the result shows average perceived stigmatization $(M=2.31, S D=0.51)$. It also shows that the sub variables of perceived stigmatization including discrimination $(M=2.35, S D=0.59)$ which indicates average perceived stigmatization, positive aspect $(M=2.27, S D=$ $0.57)$ which indicates average perceived stigmatization and lastly disclosure $(M=2.33, S D=0.58)$ which indicates also an average perceived stigmatization.

Table II. Mean and Standard deviation of the perceived stigmatization of the respondents

\begin{tabular}{|c|c|c|c|c|}
\hline VARIABLES & $\mathbf{N}$ & MEAN & SD & REMARKS \\
\hline Discrimination & 70 & 2.35 & 0.59 & Average \\
\hline Positive Aspect & 70 & 2.27 & 0.57 & Average \\
\hline Disclosure & 70 & 2.33 & 0.58 & Average \\
\hline $\begin{array}{c}\text { OVERALL } \\
\text { MEAN }\end{array}$ & $\mathbf{7 0}$ & $\mathbf{2 . 3 1}$ & $\mathbf{0 . 5 1}$ & Average \\
\hline
\end{tabular}

\section{Legend}

$0-0.79$

$0.8-1.59$

1.6- 2.39

$2.4-3.19$

3.2- 4.0

Low
Below Average
Average
Above Average
High

Stigmatization is an unfairly regarded by many people as being bad or having something to be ashamed of. The participants experience in discrimination is average, it indicates that in this level homeless people are being avoided because of their condition leading them to keep their own problems to themselves The results revealed that most of the participants are experiencing maltreatment by the people surrounds them.

On the positive aspects of homeless adolescents, the results revealed that homeless adolescents of Dasmariñas, Cavite is average, wherein the results revealed that because of being homeless, the participants become more understanding on what they are facing and tend to hide their problems. This can be associated in the research of [7] which stated that helping individuals to realize and think about their condition in a new, more positive way could result into building up self-esteem and enjoy life more.

And at the last variable, the results show that the disclosure of the homeless adolescents is fell in the average level which indicates that they are not afraid of expressing themselves to other people regardless of what they will think.

Generally, the level of perceived stigmatization of the homeless adolescents is average. This connotes that they feel life was unfair because of their situation and they also worry that someone may find out that they received donations from other people because of being a homeless, as a result,

Published By:

Blue Eyes Intelligence Engineering \& Sciences Publication (C) Copyright: All rights reserved.

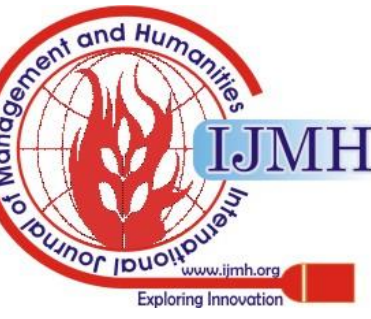


they tried to hide their problems to other people most especially to their friends and family. In relation to the study of [2], homeless are a vulnerable population in many aspect, not only they experience personal and economic hardships, but they also frequently face stigmatization and social exclusion from the other groups because of their housing status.

\section{Emotional Quotient of the Homeless Adolescents}

Table 3 present the level of emotional quotient of the homeless adolescents. Overall, the result shows average emotional quotient with $M=2.02 S D=0.46$ ) It also shows that the sub variables of average emotional quotient including emotional awareness $(M=1.96, S D=0.54)$ which indicates average emotional quotient, emotional management $(M=1.88, S D=0.61)$ which indicates average emotional quotient, social emotional awareness $(M=2.10, S D=0.58)$ and lastly relationship management $(M=2.16, S D=0.55)$ which indicates average emotional quotient.

Table III. Mean and standard deviation of the emotional quotient of the respondents.

\begin{tabular}{|c|c|c|c|c|}
\hline VARIABLES & $\mathbf{N}$ & MEAN & SD & REMARKS \\
\hline Self-awareness & 70 & 1.96 & 0.54 & Average \\
\hline Self-management & 70 & 1.88 & 0.61 & Average \\
\hline Social-awareness & 70 & 2.10 & 0.58 & Average \\
\hline $\begin{array}{c}\text { Relationship } \\
\text { Management }\end{array}$ & 70 & 2.16 & 0.55 & Average \\
\hline $\begin{array}{c}\text { OVERALL } \\
\text { MEAN }\end{array}$ & $\mathbf{7 0}$ & $\mathbf{2 . 0 2}$ & $\mathbf{0 . 4 6}$ & Average \\
\hline
\end{tabular}

\section{Legend}

$\begin{array}{ll}0-1.32 & \text { Low } \\ \text { 1.33-2.65 } & \text { Average } \\ \text { 2.66- } 4.00 & \text { High }\end{array}$

As shown in the table 3 the emotional quotient of homeless adolescents falls in average level in terms of self-awareness, where in the participants have emotional balance to deal with others and aware to recognize their feelings or emotions in their aspects of their lives. It was supported by [8] that personal competence includes awareness of self which helps a person to manage their moods and emotions and knowing one's inner world and social adeptness to rate the emotional capabilities of individual can be modify by personal and social competence.

Furthermore, the emotional management of homeless adolescents is also falls in average level where in the participants are capable to control and manage their emotions by their actions especially when they are in emotional situation.

In addition, social awareness of the participants is also falls in average level. This study showed that homeless adolescents can understand the people around them and also shows care and love with others. This is supported by the research of James Coleman 1998 one of the pioneer who made the concept of social capital as cited by [9] that social capital defined as the aspect of social structure including the network of relationship among individuals and between individuals, the community and family members that facilitate the actions within the structures. Thus, social capital is the evidenced that social relations are significant. In contrast, [10] suggest that adolescents who feel warmth and support from their parents are less likely to engage in risky behavior because nothing can succeed alone, every ones needs support from families, friends teachers and other supportive adults to grow up successfully.

Lastly, the relationship management of the participants attained in average level, which shows that participants have good interpersonal relationship to others and they can deal to some aspect of their lives even they are homeless itself. Then, since homeless are always in the street they easy to develop their interpersonal relationship to the people surrounds them or even by their friends. As stated by [11] adolescents must improve the skill on how to manage emotions in others because Goleman as cited by [11] "People who excel in these skills, do well at anything that depends on interacting smoothly with others".

Overall, the study shows that homeless adolescents obtained average level of emotional quotient where in the participants have paired and emotional balance with dealing to other people in terms of self-awareness, self-management, social awareness and relationship management. It is also stated that emotional intelligence can help people to manage their relationship effectively and suggest if people with higher levels of emotional intelligence can lead successful career and better relationships than those with low emotional intelligence [12].

Relationship between variables perceived stigmatization and emotional quotient of the homeless adolescent

Table IV. Relationship of perceived stigmatization and emotional quotient of the respondents.

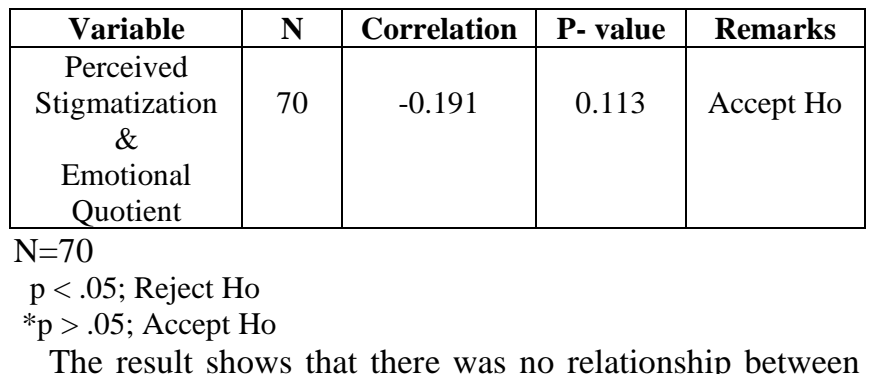
the emotional quotient and perceived stigmatization of homeless adolescents in Dasmariñas City, Cavite. The level of perceived stigmatization of the participants has no impacts to the emotional quotient of the homeless adolescents. It was supported by the study [13] stated that no matter how stigma received by the homeless, it still depends on their own decision if they want to perceive it positively or negatively.

Living in the street pushed them to think more of the situation rather than their dreams for themselves.

\section{CONCLUSION AND RECOMMENDATIONS}

The homeless adolescents have average level of perceived stigmatization in terms of discrimination. The positive aspect and disclosure also attained average level. Thus, this only means that most of homeless adolescents experienced of fair treatment in their lives. As the society view them as an unacceptable, unworthy and inferior, they were ought to prove that they can still adjust and cope to life through the style of life that they used. 


\section{Perceived Stigmatization and Emotional Quotient of the Homeless Adolescents}

In addition they also got an average level of emotional quotient in terms of self-awareness, self-management, social awareness and relationship management. The results mean that they were able to control their own emotions. Furthermore, findings of this study showed that there is no significant relationship between perceived stigmatization and emotional quotient of homeless adolescents.

The Municipal Social Welfare Development, community helpers in coordination with the intervention program provided may help to deliver the needs and support to the homeless adolescent such for their necessities. The program will help the homeless to develop more their emotional capabilities to reach their dreams through continuing their education and practicing their skills and talent in different fields to overcome the circumstances and show the desire to improve their lives and possibilities.

\section{REFERENCES}

1. Steinhardt, M. (2013). Stigma of homelessness. Retrieved from https://repository.wlu.edu/bitstream/handle/11021/24196/Steinhardt_ Poverty_2009_wm.pdf?sequence=1\&isAllowed=y .

2. Johnstone, M., Jetten, J., Dingle, G. A., Parsell, C., \& Walter, Z. C. (2015). Discrimination and well-being amongst the homeless: the role of multiple group membership. Frontiers in Psychology. doi:10.3389/fpsyg.2015.

3. Dingle, G.A, Cruwys, T., Frings, D (2015), Social identities as pathways into and out of addiction Frontiers in Psychology, 6 10.3389/fpsyg.2015.01795

4. Benny, A. (2014). The mental, educational, emotional and physical effects on homeless adults. Retrieved from https://prezi.com/thhaft8x8_zx/the-mental-educationalemotional-and-physical-effects-on-homeless-adults/

5. Medianna, P., \& Hassan, S. (2015). A review on emotional intelligence among homosexual of LGBT community. Retrievedfrom http://scialert.net/abstract/?doi=ajsr.2015.14.21

6. Lauren, F. (2013). The impact of emotional recognition on prejudice and

discrimination.Retrievedfromhttps://deepblue.lib.umich.edu/bitstream /handle/2027.42/98929/lfrisch.pdf;sequence=1

7. Judy Kuriansky. Ecopsychology. Sep 2013.S-30-S-37.http://doi.org/10.1089/eco.2013.0010

8. Mukherjee, S.(2016). Importance of Emotional Intelligence in theOrganizations. Retrieved from http://www.linkedin.com/pulse/importance-emotional-intelligence-or ganizations-sunayana-mukherjee

9. Banchevska, D., Harinng, S., Dashora, P., Glebova, T., \& Slesnick, N. (2008). Problem behaviors of homeless youth: A social capital perspective. Journal of Human Ecology, 23(4), 285-293. Retrieved from https://goo.gl/eIwYAT

10. Levy, S., (2018). Behavioral problems in adolescents. Retrieved from https//www.merckmanuals.com/home/children-s-health-issues/proble ms-in-nadolescents/behavioral-problems-in-adolescents

11. Espina, R.,V. \& Santos, E. (2005) Perceived parenting style and its relation to the emotional intelligence quotient of the selected eldest adolescents of University of Perpetual Help System- Dalta of school year 2004-2005. Undergraduate thesis, De La Salle University-Dasmarinas

12. Gill, G. (2017). The role of emotional intelligence in managing relationship.Retrieved from http:// www.psychreg.corg/emotional-intelligence-relationships/

13. Amago, L., Decena, H., \& Parientes, G. (2017). Self-concept, interpersonal relationship and emotional quotient among orphan and non-orphan adolescents. Unpublished Undergraduate Thesis, Cavite State University.

14. Children Trends Databank. (2015). Homeless children and youth. Retrieved https://www.childtrends.org/indicators/homeless-children-and-youth.

\section{AUTHORS PROFILE}

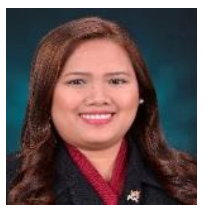

Ulanday, Ma. Leah Pacleb, finished her college degree in Nursing and took Teacher's Certificate Program and Master's degree in Education. Her research work includes developmental research in Education, Gender- Based, Social science and/or Humanities
Research. A faculty member of Cavite State University, Coordinator of National Service Training Program and one of the Gender and Development Focal Person of the University. A co- author of an extension program implemented by CvSu- Silang Campus, a proud member of Philippine Society of NSTP Educators and Implementers, INC., Faculty researcher and extensionist, GAD Advocate, a graduate nurse and a licensed professional teacher.

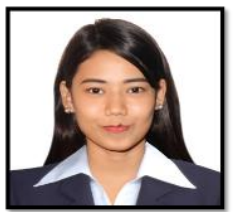

Abando, Marie Christine A Finished her college degree of Bachelor of Science in Psychology at Cavite State University- Silang Campus. She works as an HR Intern at Tetra Sales and Inc. Her interest includes travelling and working with her friends in the community.

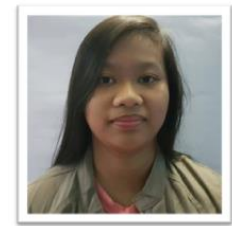

Belardo, Einon Dane Kryzl O. Finished her college degree of Bachelor of Science in Psychology at Cavite State University- Silang Campus. She works as an Intern at Lifelife Rehabilitation Center

Her interest includes research, community outreach, and volunteering work in the field of Psychology.

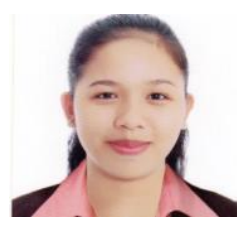

Loreto, Efephany Joy N. Finished her college degree of Bachelor of Science in Psychology at Cavite State University- Silang Campus. Presently, She works in Maguad Psychological Clinic asStaff. Her interest includes listening to relaxing music, photography, dancing and teaching.

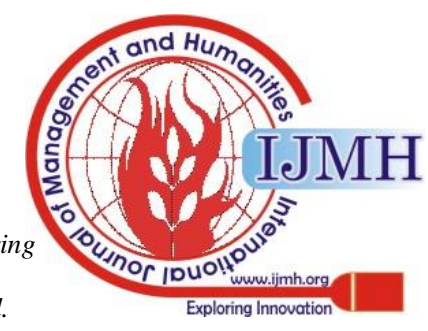

